DOI: https://doi.org/10.47405/mjssh.v5i12.590

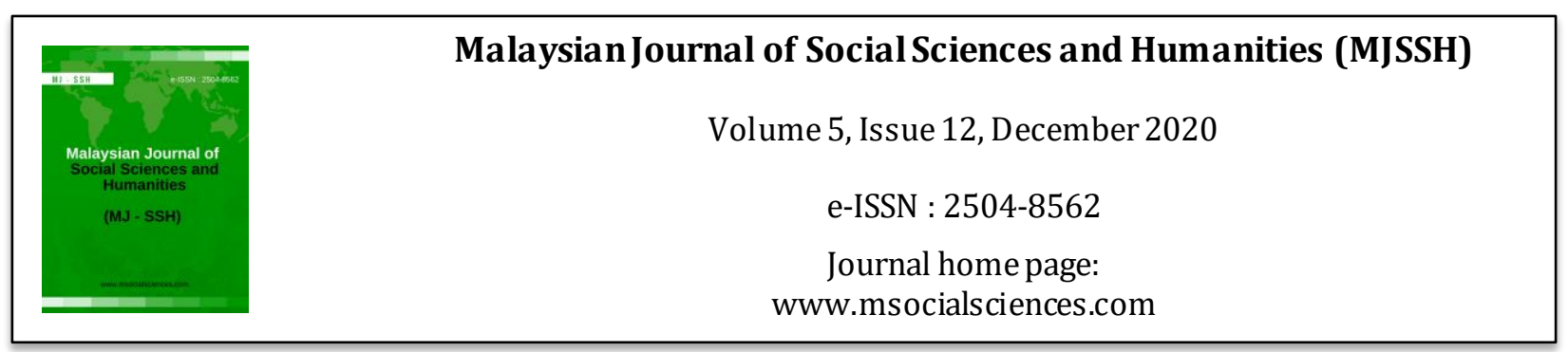

\title{
Seks Sebelum Nikah: Konsep Janji Temu dan Cinta Mengikut Perspektif Islam
}

\author{
Abdul Rashid Abdul Aziz', Nor Hamizah Ab Razak' ${ }^{1}$, Rezki Perdani Sawai', Husin² \\ ${ }^{1}$ Fakulti Kepimpinan dan Pengurusan, Universiti Sains Islam Malaysia (USIM) \\ ${ }^{2}$ Fakultas Tarbiyah, STIQ, Amuntai, Indonesia \\ Correspondence: Abdul Rashid Abdul Aziz (rashid@usim.edu.my)
}

\begin{abstract}
Abstrak
Isu seks sebelum nikah dalam kalangan remaja di Malaysia kian meningkat dan menymbang kepada pertambahan kes kehamilan anak luar nikah. Keadaan ini berlaku disebabkan oleh kurangnya pemahaman berkaitan konsep janji temu dan cinta menurut ajaran Islam. Justeru, penulisan ini bertujuan untuk mengenal pasti konsep janji temu dan cinta. Seterusnya, mengkaji janji temu dan konsep cinta dalam Islam serta solusi berhubung dengan natijah daripada penyimpangan dalam tingkah laku seks bebas ekoran daripada salah fahaman terhadap konsep sebenar janji temu dan cinta. Maklumat yang diketengahkan adalah berdasarkan kajian perpustakaan melalui kaedah analisis kandungan. Konsep janji temu dan cinta menurut perspektif Islam dibincangkan secara terperinci dan diadun bersama teori segi tiga Sternberg dalam memahami permasalahan yang berlaku. Dapatan kajian mendapati bahawa terdapat pelbagai elemen penting dalam konsep janji temu dan cinta menurut Islam yang seterusnya menyumbang kepada solusi terhadap isu seks sebelum nikah. Tuntasnya, pengkajian seperti ini amatlah relevan dalam membantu mengawal kebejatan sosial yang berleluasa di negara kita.
\end{abstract}

Kata Kunci: janji temu, cinta, seks luar nikah, remaja

\section{Sex Before Marriage: The Concept of Dating and Love According to The Islamic Perspective}

\begin{abstract}
The issue of premarital sex among teenagers in Malaysia is increasing and contributes to the increment of illegitimate pregnancies cases. This situation occurs due to the lack of understanding related to the concept of dating and love according to Islamic perspective. Thus, this study aims to identify and explore the concept of dating and love. Meanwhile, it also discusses the solutions related to the consequences of deviations from the true concept of dating and love as a result of a misunderstanding of the concept. This is a library research where content analysis methods was used. The concept of dating and love according to the Islamic perspective was discussed in detail and blended with Sternberg's triangular theory in understanding the problems occurred. The study found that there are various important elements in the concept of dating and love according to Islam which in turn contributes to the solution to the issue of premarital sex. Ultimately, this study is very relevant in helping to control the widespread of social depravity in our country.
\end{abstract}

Keywords: dating, love, sexuality, teenagers, adolescent 


\section{Pengenalan}

Manusia dilahirkan dengan fitrah untuk mencintai dan dicintai oleh insan lain. Secara umumnya, perkataan fitrah boleh diertikan sebagai sifat semula jadi (Rumaya Juhari \& Rozumah Baharudin, 2004; Nurul Wahidah, Siti Nor Baya, Syaimak \& Nasaruddin, 2015) atau kecenderungan dan bawaan alamiah manusia (Muliya, 2016). Setiap manusia lahir dengan fitrah yang telah ditetapkan oleh Allah SWT. Antara fitrah atau kecenderungan manusia yang lain ialah fitrah bertauhid (mengesakan Tuhan), fitrah beragama, fitrah berfikir, fitrah inginkan kebebasan dan fitrah untuk memenuhi keperluan jasmani (makan, minum, berpakaian). Menurut Muliya (2016), kesemua fitrah ini boleh dikategorikan kepada tiga iaitu fitrah ruhaniyyah (rohani), fitrah nafsiyyah (nafsu) dan fitrah jasmaniah (jasmani). Glasser (1999) menyatakan bahawa rasa kasih dan ingin dimiliki (love and belonging) merupakan keperluan asas manusia. Pendapat ini adalah selari dengan teori hierarki keperluan Maslow (1943). Dalam teori ini, terdapat lima peringkat keperluan manusia iaitu; pertama, keperluan asas; kedua, keperluan keselamatan dan jaminan diri; ketiga, keperluan untuk berkasih-sayang; keempat, keperluan untuk penghormatan diri; dan yang terakhir ialah keperluan untuk pencapaian diri (Ridzuan, Arman, \& Razlina, 2018). Maka jelaslah bahawa manusia memerlukan kasih sayang dalam melayari hidup di dunia.

Dalam hubungan cinta, keinginan untuk berjanji temu (dating) dan menjalinkan hubungan seksual (sexuality) adalah perkara biasa yang dialami oleh kebanyakan pasangan bercinta terutamanya di peringkat awal percintaan dan di usia remaja. Syaidatun Nazirah dan Maslawati (2019) melaporkan remaja Melayu telah mula bertemu janji seawal usia di antara 13 hingga 15 tahun, dan mereka sudah mula melakukan perlakuan seksual seperti mencium dan meraba pasangan masing-masing seawal usia di antara 16 hingga 17 tahun. Kebanyakan remaja menerima perlakuan intim seperti berpeluk, bercium dan hubungan seks antara pasangan kekasih sebagai suatu gaya hidup yang normal. Walau bagaimanapun, perbuatan tersebut adalah bertentangan dengan ajaran Islam. Islam telah memberikan panduan berkaitan dengan pergaulan antara lelaki dan wanita untuk mengelakkan daripada berlakunya perkara-perkara yang mendorong kepada memenuhi keinginan seksual. Antaranya ialah merendahkan pandangan, memelihara kemaluan dan menjaga aurat (Rezki, 2019; Nur 'Izzah \& A'dawiyah, 2018). Malangnya, remaja kurang memahami maksud sebenar konsep janji temu dan cinta sebenar menurut perspektif Islam sehingga menyebabkan remaja mudah terjebak dengan hubungan yang boleh merosakkan diri mereka (Noraini, 2001; Zulaiha et al., 2016).

Umumnya, perbincangan mengenai seksualiti adalah dikaitkan dengan alat kelamin atau hal-hal yang berhubungan dengan aspek atau perkaitan mengenai hubungan intim yang berlaku di antara dua individu yang biasanya adalah di antara lelaki dan perempuan (Zainun, 2002). Namun, seksualiti merangkumi aspek yang lebih luas dan bukan hanya melibatkan hubungan kelamin semata-mata, untuk itulah para pengkaji turut berpandangan bahawa tingkah laku seksual mempunyai peranan yang unik di dalam menentukan kehidupan manusia. Seksualiti menurut Makzan (2001) adalah satu aspek yang merupakan sebahagian daripada tingkah laku manusia itu sendiri. Tingkah laku ini juga mempengaruhi cara individu berfikir, merasa, berpakaian, bermain, berkasih sayang dan berkelamin. Untuk itulah, maka terdapat ramai pengkaji yang mengkaji mengenai seksualiti dan dikaitkan dengan kehidupan manusia. Makzan (2001) menyatakan Sigmund Freud umpamanya adalah merupakan tokoh utama yang mengkaji dan cuba mengaitkan aspek seksualiti sebagai satu bahagian dalam perihal personaliti manusia itu sendiri. Hal ini menunjukkan bahawa elemen seksual memainkan peranan yang penting dalam kehidupan manusia. Bahkan, komponen nafsu juga melibatkan dorongan ke arah hubungan yang romantik, tarikan fizikal dan kemahuan seksual rentetan rasa cinta yang melahirkan rasa kebahagiaan apabila bersama (Noraini, 2000; Ulwan, 2012).

Terdapat pelbagai isu yang dikaitkan berhubung janji temu dan cinta sehingga menimbulkan kebejatan sosial dalam kalangan golongan muda. Di antaranya isu hubungan seks bebas dan juga semasa pertemuan (Date Rape) atau juga disebut isu perogolan semasa janji temu. Menurut Patterson (2005), antara perlakuan seks yang biasanya ditunjukkan oleh remaja lelaki semasa janji temu ialah bermula dengan membuat lawak atau komen mengenai seks, lelaki cuba untuk secara 'main-main' memeluk dan meraba pasangannya atau meminta pasangan memberikan 'good night kiss'. Pemerkosaan atau date rape semasa janji temu boleh berlaku di kalangan remaja tanpa mengira batasan kerana apabila 
pasangan mula bercinta ataupun keluar berdua, terdapat kecenderungan untuk berlaku hubungan seks sebelum nikah di peringkat ini kerana remaja sukar untuk mengawal dorongan nafsu yang ada dalam diri mereka. Isu ini seterusnya akan menular kepada masalah sosial yang lain seperti buang anak, kelahiran anak luar nikah dan seks bebas.

Keadaan menjadi semakin parah apabila golongan remaja hari ini semakin hanyut dengan aktiviti maksiat iaitu seks bebas sebelum nikah. Menurut Mohd Fauzi \& Mohd Khairul (2012), gejala seks bebas sebelum nikah, pengguguran anak dalam kandungan, kelahiran anak luar nikah dan pembuangan bayi dalam kalangan remaja hari ini bukan lagi menjadi suatu perkara asing dalam masyarakat. Tidak kurang juga ada remaja sanggup mengorbankan keluarga sendiri dengan lari dari rumah untuk tinggal bersekedudukan dengan teman lelaki (Mohd Razimi et al., 2020). Berdasarkan angka statistik, sebanyak 9 peratus daripada jumlah keseluruhan pelajar di kelas peralihan seluruh negara dikesan cergas dalam hubungan seks (Safeek, 2019). Malah menurut tinjauan yang dibuat oleh Morbiditi dan Kesihatan Kebangsaan (National Health and Morbidity Survey, NHMS) mendapati lebih 35 peratus pelajar Malaysia pernah melakukan hubungan seksual sebelum umur 14 tahun (NHMS, 2017). Manakala, seramai 3,694 orang remaja hamil luar nikah (Kementerian Kesihatan Malaysia, 2017). Daripada jumlah ini, dianggarkan, terdapat 300 kes hamil luar nikah telah berlaku setiap bulan. Fenomena ini pada dasarnya bermula dengan janji temu dan cinta dalam kalangan remaja. Ini kerana dalam usaha untuk mencintai dan dicintai, terdapat remaja yang lupa kepada tuntutan syariat dan kepentingan memelihara akhlak sepanjang menjalinkan cinta tersebut (Syaidatun et al., 2014). Akibatnya, berlakulah isu-isu seperti masalah seksual.

Isu seksual dalam kalangan remaja kian meningkat dan turut memberi implikasi kepada kehamilan anak luar nikah. Berdasarkan maklumat daripada Perangkaan Jabatan Pendaftaran Negara, data antara 2010 hingga 2018 lalu menunjukkan jumlah anak tidak sah taraf beragama Islam ialah seramai 172,811 orang. Ini bermakna, secara purata lebih kurang 2000 kes anak luar nikah direkodkan setiap bulan. Tidak kurang juga dengan isu pembuangan bayi yang kian meningkat saban tahun. Berdasarkan statistik mendapati sejumlah 577 kes pembuangan bayi dan janin direkodkan antara Januari 2014 hingga Disember 2018 (Metro Online, 2020). Angka ini menunjukkan berlakunya peningkatan kes penzinaan dan hubungan seks terlarang dalam kalangan remaja. Oleh yang demikian, penulisan ini bertujuan untuk mengenal pasti konsep janji temu dan cinta. Seterusnya, mengkaji janji temu dan konsep cinta dalam Islam serta solusi berhubung dengan natijah daripada penyimpangan dalam tingkah laku seks bebas ekoran daripada salah fahaman terhadap konsep sebenar janji temu dan cinta.

\section{Sorotan Literatur}

\section{Takrifan Janji Temu dan Cinta}

Janji temu adalah langkah permulaan dalam proses mengenali seseorang yang diminati dan kemudiannya setelah halangan emosi seperti rasa malu, takut dan ragu-ragu di atasi, remaja akhirnya akan berkongsi minat, kegemaran dan perasaan dengan orang yang dikasihi tersebut. Janji temu juga disebabkan oleh perubahan fisiologi dan biologi semasa tempoh remaja, tekanan sosial dan persekitaran yang berkait rapat dengan perkembangan fizikal, emosi dan sosial. Menurut Jas Laile (2002), yang memetik pernyataan Douvan dan Adelson (1966) serta Place (1975), remaja mula berani janji temu dengan pasangannya sekitar umur 14 hingga 15 tahun. Menurut takrifan Whitney et al. (2000) serta Havelin dan Kate (2000), janji temu di definisikan sebagai aktiviti sosial yang dilakukan oleh pasangan dengan niat untuk menilai kesesuaian pasangan mereka sebagai teman intim dan seterusnya sebagai pasangan hidup.

Umumnya, janji temu ialah pertemuan yang dilakukan oleh dua orang atau lebih atas tujuan peribadi meliputi aspek perkenalan dan kesesuaian bagi menjalankan hubungan intim yang lebih serius seperti cinta. Namun, untuk tujuan pertemuan yang berorientasikan kerja, pelajaran, perbincangan dan urusanurusan lain, istilah 'going with', 'seeing', 'meeting' akan digunakan. Kebanyakan orang mengatakan janji temu dan istilah courtship adalah proses yang sama yang merujuk kepada hubungan di antara lelaki dan perempuan, namun courtship adalah satu sifat atau tingkah laku bagi mereka yang telah 
meningkat dewasa yang tujuan akhirnya adalah untuk memilih pasangan hidup untuk berkahwin manakala janji temu pula lebih kepada keinginan yang bersifat jangka pendek tanpa sebarang niat yang mendalam seperti untuk perkahwinan.

Di dalam Dictionary of Psychology (1996), cinta ialah perasaan kasih sayang yang mendalam dan kuat berbanding dengan suka. Cinta dikaitkan dengan elemen romantik dan tarikan seksual kepada seseorang. Menurut Mohamed Hatta (1994), golongan remaja biasanya sukar untuk membuat penilaian antara cinta monyet atau cinta semesta. Cinta monyet ditakrifkan sebagai cetusan perasaan semusim sahaja dan tidak akan bertahan lama. Manakala remaja juga berupaya menjalin cinta semesta yang bukan sahaja lebih mantap tetapi juga dapat bertahan lebih lama daripada cinta monyet. Cinta semesta melibatkan kasih sayang kepada ibu bapa, ahli keluarga dan masyarakat.

Cinta membawa maksud luahan hati yang berkaitan dengan kasih sayang dan pernyataan emosi. Secara kebiasaannya, ia adalah berkaitan dengan perhubungan cinta antara pasangan. Cinta ialah perlakuan yang dilakukan dengan sengaja bagi memaparkan kecenderungan terhadap orang lain, untuk menggalakkan persekitaran dan perhubungan yang mesra (Thomas, 2010). Rubin (1973) di dalam Makzan (2001), menyatakan bahawa cinta terdiri daripada tiga komponen. Komponen pertama adalah mengambil berat iaitu perasaan kepuasan bahawa pihak yang satu lagi adalah sama penting dengan diri sendiri. Komponen kedua adalah ikatan atau keinginan untuk bersama di antara pasangan dan komponen ketiga pula keintiman yang melibatkan komunikasi yang rapat serta bersifat rahsia. Gabungan daripada ketiga-tiga komponen ini lahirlah perasaan yang dinamakan cinta. Menurut Fadzilah dan Syaidatun (2005) rumusan yang dibuat dalam konsep cinta masyarakat barat ialah menitikberatkan tarikan dan penampilan luaran (fizikal) iaitu semakin cantik dan tampan akan membuatkan lebih ramai individu yang akan mencintai dan tertarik. Selain itu, cinta sering disulami dengan hubungan seks sehingga konsep kesetiaan antara pasangan semakin terhakis. Masyarakat barat juga lebih bergantung sepenuhnya kepada individu yang dicintai tanpa pergantungan serta cinta kepada tuhan.

\section{Takrifan Janji Temu dan Cinta dalam Islam}

Menurut Islam, janji temu adalah satu pertemuan keluar bersama di antara individu berlainan jantina yang bukan dari muhrimnya tanpa ditemani oleh orang ketiga untuk bertindak sebagai saksi atau pemerhati. Janji temu yang tidak bertujuan ke arah ikatan perkahwinan adalah ditegah kerana mendorong kepada maksiat dan juga fitnah. Perhubungan di antara lelaki dan perempuan mesti diasaskan kepada niat yang baik dan suci iaitu bertujuan untuk berkahwin demi menegakkan sebuah rumah tangga yang diredhai Allah. Justeru sebarang perhubungan yang tidak bertujuan untuk ke arah perkahwinan adalah haram bertepatan dengan firman Allah dalam Surah An-Nur ayat 30 yang bermaksud;

\footnotetext{
"Katakanlah kepada laki-laki yang beriman, Hendaklah mereka menahan pandangannya, dan memelihara kemaluannya; yang demikian itu adalah lebih suci bagi mereka, sesungguhnya Allah Maha Mengetahui apa yang mereka perbuat".
}

Dalil ini menjelaskan larangan seorang lelaki melihat bahagian tubuh wanita melainkan wajah dan telapak tangan. Ini kerana, selain daripada bahagian tersebut adalah aurat bagi wanita. Namun, sekali pun perbuatan temu janji yang mengikuti atau menepati larangan tersebut, namun perbuatan tersebut tetap merupakan perbuatan yang menghampiri kepada maksiat. Perkara ini dijelaskan dalam firman Allah dalam Surah Al-Isra' (17:32) maksudnya,

"Dan janganlah kamu menghampiri zina, sesungguhnya zina itu adalah satu perbuatan yang keji dan satu jalan yang jahat (yang membawa kerosakan).”

Menurut Islam, takrifan cinta bukan hanya kepada cinta sesama manusia tetapi yang paling utama adalah cinta agung dan hakiki iaitu cinta kepada Allah SWT. Menurut Abdullah Nashih (2007), cinta merupakan perasaan jiwa, getaran hati, pancaran naluri dan terpautnya hati orang yang mencintai pada 
pihak yang dicintainya, dengan semangat yang menggelora dan wajah yang selalu menampilkan keceriaan. Cinta ini benar-benar semula jadi dan berkekalan selagi mana seseorang itu tidak melampaui batas yang ditentukan oleh Allah SWT. Walau bagaimanapun Islam tidak menolak cinta bahkan cinta adalah anugerah yang unik dari Allah terhadap hambanya. Cinta juga adalah keperluan dalam hidup dan jalan untuk mengenali dan membesarkan Allah SWT sebagaimana yang jelaskan oleh Allah dalam ayat 49 surah Az-Zaariyat yang bermaksud;

"Dan segala sesuatu Kami ciptakan berpasang-pasangan supaya kamu mengingati kebesaran Allah SWT."

Berdasarkan kalam al-Quran di atas, dapat disimpulkan bahawa cinta yang berlandaskan agama melalui ikatan sah seperti perkahwinan akan membawa seseorang mendekati agama dan mengikut jalan mengenal Allah SWT.

\section{Kajian berkaitan Janji Temu dan Cinta}

Janji temu dan cinta bukanlah sesuatu yang asing dalam kalangan masyarakat di Malaysia khususnya dalam kalangan remaja. Menurut WHO (World Health Organisation), peringkat remaja adalah antara umur 12 hingga 24 tahun dan fasa remaja merupakan peringkat peralihan dari alam kanak-kanak ke alam kedewasaan. Alam remaja amat mencabar di mana remaja mengalami pelbagai perubahan fizikal, intelek dan emosi yang boleh menimbulkan konflik dalam diri dan persekitarannya. Dalam fasa remaja juga telah terbentuk perasaan ingin disayangi dan menyayangi sekali gus merupakan petunjuk kepada kematangan seksual dan reproduktif seseorang remaja itu (Zulaiha et al., 2016).

Menurut Abdullah (2007), remaja juga adalah golongan yang sering kali didekati oleh Rasulullah SAW. Baginda SAW telah memberikan perhatian yang jitu terhadap pembentukan nilai-nilai moral dan perkembangan keperibadian remaja untuk membentuk ketahanan diri mereka menghadapi cabaran dengan kekuatan iman serta kesabaran melaksanakan peranan sebagai hamba. Ini menjelaskan bahawa usia remaja adalah tempoh yang kritikal di mana remaja bukan sahaja bergelut dengan cabaran luaran, malah juga perlu menguruskan perubahan semula jadi dalam diri termasuklah kehadiran perasaan untuk berkasih sayang.

Oleh yang demikian, memiliki kekasih ketika usia remaja bukan sesuatu yang mengejutkan. Ini adalah senario yang berlaku ketika usia meningkat 14 dan 15 tahun, remaja sudah mula tertarik antara satu sama lain (Azizi \& Asiah, 2006). Dalam masa yang sama, percintaan sebelum perkahwinan menjadi satu trend atau gaya hidup remaja Islam rentetan pengaruh budaya asing. Pelbagai istilah yang pada asalnya baik telah dinodai oleh individu yang terjerumus dalam bahana cinta. Antara nya adalah seperti istilah 'couple' yang pada asalnya merujuk kepada pasangan suami dan isteri berkahwin, namun telah terpesong kepada maksud muda-mudi yang hangat bercinta. Begitu juga dengan istilah khalwat yang pada asalnya merujuk kepada berkhalwat dengan Allah iaitu mengabdikan diri beribadah, namun telah digunakan merujuk kepada perbuatan yang tidak baik iaitu berdua-duaan di antara berlainan jantina yang bukan muhrim.

Kajian daripada Azizi dan Asiah (2006) telah mendedahkan kebanyakan pelajar mengakui sering berpegangan tangan dengan kekasih dan sanggup melakukan apa sahaja demi membuatkan pasangan bahagia. Dapatan kajian ini sangat membimbangkan kerana jelas bertentangan dengan ajaran Islam serta menyumbang kepada berlakunya isu-isu moral dalam kalangan remaja yang merupakan tonggak utama peneraju agama, bangsa dan negara pada masa hadapan. Oleh itu kefahaman tentang kesan daripada pentingnya pendidikan keagamaan serta sistem keluarga yang berfungsi dapat mengelak dari berlakunya masalah sosial akibat daripada janji temu dan cinta khususnya dalam kalangan remaja. Pemahaman terhadap hakikat cinta yang sebenar dan juga pengurusan perasaan cinta dapat membantu remaja mencegah diri dari terjebak dalam gejala bercinta. 


\section{Kajian Berkaitan Seksualiti Remaja}

Menurut Arnett (2001), menerusi aktiviti seksualiti bebas remaja telah menghasilkan beberapa kesan negatif ke atas diri para remaja. Antara kesan negatif akibat aktiviti seksualiti tersebut adalah, mengandung luar nikah (pregnancy), pembuangan kandungan (abortion) dan juga terpaksa menjalankan tanggungjawab sebagai penjaga dalam usia muda (parenthood in adolescent). Hasil dari dapatan kajian yang dilakukan di Amerika Syarikat oleh Schellenberh, Whitman dan Borkowski (1992) di dalam Arnett (2001), telah mendapati bahawa 40 peratus dari kalangan remaja telah mengandung secara tidak terancang, di mana ia berakhir dengan pengguguran janin dalam kandungan. Selain itu, remaja terbabit juga 10 peratus daripadanya mengalami keguguran, sementara 5 peratus remaja wanita mengandung telah diasuh oleh pekerja atau badan khidmat sosial. Namun, masih terdapat 45 peratus remaja perempuan mengandung tersebut dipelihara oleh ibu bapa atau waris remaja terbabit.

Banyak tokoh psikologi seperti Freud, Levy, Koch dan Kinsey menyatakan bahawa pertumbuhan kelenjar-kelenjar seks secara biologi menimbulkan dorongan seksual dalam diri seseorang remaja. Secara biologinya setiap remaja secara berperingkat-peringkat melalui tahap-tahap perkembangan seksualiti yang agak setara, tetapi secara umum setiap budaya sebenarnya mempunyai pandangan yang berbeza mengenai seksualiti ini. Justeru itu, disebabkan asas ini, maka wujud perbezaan di antara satu budaya dengan budaya yang lain terhadap seksualiti terutamanya yang berkaitan dengan remaja (Mappiare, 1982).

Hasilan dari penyelidikan yang dilakukan oleh beberapa pakar di Amerika Syarikat, maka Gullotta et al. (2000) telah membuat kesimpulan bahawa wujud peningkatan dan keterlibatan yang ketara di kalangan para remaja dalam aktiviti persetubuhan atau hubungan seks luar nikah yang dilakukan oleh para remaja. Aktiviti persetubuhan ada sebahagiannya telah dilakukan seawal usia 13 tahun. Antara punca berlakunya penzinaan atau hubungan kelamin luar nikah seawal usia remaja di kalangan masyarakat Barat adalah disebabkan oleh beberapa faktor, di antaranya ialah janji temu di awal usia remaja serta kurang pegangan agama yang kukuh dalam diri.

Hubungan keluarga yang tidak akrab akan menyebabkan hubungan seks luar nikah. Ini terbukti menerusi kajian oleh Taris dan Seman (1997) yang menyatakan bahawa ibu bapa masyarakat AfricanAmerican mencegah kelakuan seks di kalangan remaja mereka, dan sekiranya hubungan kekeluargaan tidak akrab dan berunsur negatif dalam kalangan keluarga mereka, maka ia akan menyebabkan remaja terjebak ke kancah hubungan seks luar nikah seawal usia remaja. Menurut Arnett (2001) menerusi kajian secara meluas terhadap perspektif sosialisasi seksual iaitu berhubung transisi daripada remaja kepada seksual dewasa menyatakan bahawa secara sosialisasinya, seksualiti dapat dibahagikan kepada 3 komponen iaitu sosialisasi seksual dalam masyarakat terikat (restrictive), sosialisasi seksualiti dalam masyarakat separa terikat (semi-restrictive) dan seterusnya ialah sosialisasi seksualiti dalam masyarakat tidak terikat (permissive).

\section{Metod Kajian}

Kajian kualitatif ini menggunakan kaedah kajian perpustakaan untuk mencari maklumat sekunder yang berkaitan dengan isu yang dikaji. Maklumat-maklumat yang diperoleh adalah daripada pelbagai sumber seperti buku, jurnal, dan majalah. Maklumat ini dikumpulkan dan disaring serta dianalisis menggunakan teknik analisis kandungan. Teknik analisis kandungan terhasil apabila pengkaji mempunyai matlamat untuk menjalankan kajian literatur. Ia dimulakan dengan menyediakan latar belakang terhadap kandungan kajian literatur yang hendak dijalankan. Seterusnya pengkaji membaca dan memahami bahan literatur yang diperoleh. Akhirnya, pengkaji mengintegrasikan bahan bacaan tersebut kepada pengetahuan yang dimiliki oleh pengkaji. Daripada analisis yang dijalankan, maka terhasillah pemahaman berkaitan konsep janji temu dan cinta mengikut perspektif Islam serta hubung kaitnya dalam pembentukan keluarga bahagia. 


\section{Hasil Kajian \& Perbincangan Kajian}

\section{Konsep Janji Temu dan Cinta}

Menurut Kett (1977) di dalam Thomas et al. (2000), janji temu telah berlaku seawal zaman penjajahan di Amerika. Pada masa tersebut, terdapat bukti yang menunjukkan remaja Amerika berjumpa untuk tujuan berasmara. Selain itu, penjajah di Amerika juga telah mengamalkan janji temu dengan memperkenalkan satu budaya yang kurang baik dikenali sebagai 'bundling' yang merupakan perbuatan lelaki dan perempuan yang mengunjungi tempat tidur (katil) masing-masing yang hanya dipisahkan oleh sekeping papan kayu, manakala Rothman (1987) di dalam Thomas et al. (2000), menyatakan bahawa pada hujung era 1700 , telah berlaku penurunan dalam sekatan melakukan hubungan seks sebelum berkahwin. Hal ini berikutan dengan budaya 'bundling' yang diamalkan sehingga mengakibatkan kelahiran bayi sebelum perkahwinan bagi satu pertiga pasangan yang berkahwin pada zaman penjajahan tersebut. Menurut Burchinal (1969) di dalam Jas Laile (2002), terdapat dua corak janji temu yang dilakukan oleh para remaja, iaitu pertamanya ialah janji temu persaingan yang bermaksud satu persaingan untuk memperoleh pasangan janji temu dan sering bertukar-tukar pasangan tanpa sebarang tanggungjawab jika hubungan kemesraan gagal diteruskan. Keduanya ialah janji temu berkomitmen yang merujuk kepada kedua-dua pasangan janji temu atas dasar setia di antara satu sama lain dan juga merasakan bahawa mereka kekal berpasangan.

Menurut Sternberg (1986) di dalam Makzan (2001) kefahaman tentang konsep cinta dapat dilihat berdasarkan tiga komponen yang membentuk model tiga segi cinta. Model ini memperlihatkan bagaimana ketiga-tiga komponen yang bergabung ini melahirkan beberapa bentuk hubungan dalam percintaan. Komponen pertama ialah keintiman iaitu kedekatan yang mengukuhkan ikatan perhubungan antara dua individu. Ia juga melibatkan satu perasaan ingin selalu berada berhampiran dengan seseorang dan mengambil berat termasuklah persefahaman, saling menyokong antara satu sama lain dan boleh berbincang secara terbuka sesama sendiri mengenai perkara yang tidak dibincangkan dengan orang luar. Komponen kedua melibatkan nafsu ghairah merangkumi romansa, perhubungan seksual dan melibatkan tarikan fizikal. Ia melibatkan pelbagai emosi seperti nafsu, kegembiraan dan lain-lain. Komponen ketiga pula ialah komitmen jangka panjang dan jangka pendek. Komitmen jangka pendek memperlihatkan apabila seseorang mengambil keputusan untuk mencintai pasangannya. Komitmen jangka panjang pula melibatkan usaha untuk mengekalkan hubungan percintaan yang sedia ada.

Rajah 1: Jenis cinta berdasarkan teori segi tiga Sternberg

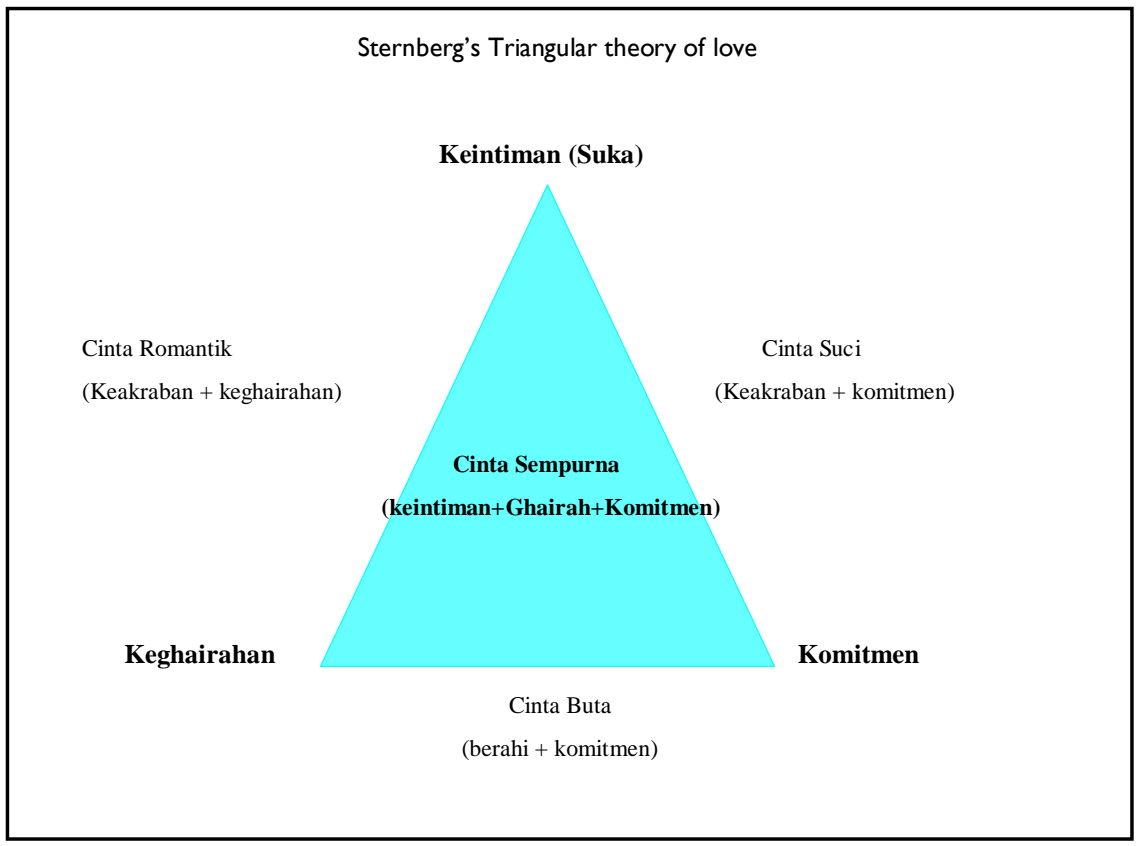

Sumber: Sternberg (1986) di dalam Mohd Makzan Musa (2001) 
Berdasarkan gambar rajah di atas, keintiman melibatkan elemen suka bukannya cinta. Ia merujuk kepada hubungan persahabatan tanpa cinta atau komitmen jangka panjang. Cinta romantik pula melibatkan keintiman dan nafsu ghairah. Pasangan kekasih saling tertarik dengan keadaan fizikal dan emosi antara satu sama lain tanpa melibatkan komitmen. Seterusnya cinta suci pula melibatkan keintiman dan komitmen antara pasangan. Komitmen yang dimaksudkan ialah komitmen jangka panjang seperti perkahwinan di mana nafsu ghairah telah luntur. Komponen keghairahan ialah cinta berahi yang melibatkan nafsu ghairah semata seperti cinta pandang pertama tanpa keintiman atau komitmen. Komponen komitmen pula ialah cinta kosong kerana sekadar komitmen dan membuat keputusan (untuk mencintai) tanpa keintiman atau nafsu (ghairah). Cinta bodoh atau cinta buta adalah komponen yang terletak di bawah iaitu melibatkan nafsu ghairah dan komitmen (komitmen berdasarkan nafsu ghairah tetapi tiada keintiman untuk membentuk perhubungan). Komponen cinta yang terdapat di tengah-tengah segi tiga ialah cinta sempurna yang melibatkan ketiga-tiga komponen iaitu komitmen, ghairah dan keintiman.

\section{Janji Temu dan Cinta dalam Perspektif Islam}

\section{Janji temu dalam PerspektifIslam}

Menurut perspektif ajaran Islam, janji temu dalam erti kata berdua-duaan pasangan lelaki perempuan yang bukan mahram adalah haram di sisi agama. Larangan tersebut adalah kerana perbuatan janji temu itu boleh membawa kepada mudarat. Mudarat yang dimaksudkan ialah dengan janji temu, maka ia akan mendedahkan pasangan lelaki dan perempuan melakukan sesuatu yang ditegah dalam agama Islam (Farid, 2008). Bahkan beliau menekankan bahawa dengan janji temu juga, maka proses evolusi ke arah berlakunya penzinaan akan berkembang, ini dapat dilihat kepada proses yang berlaku di mana pada mulanya, peringkat janji temu adalah menerusi mesej dan telefon, kemudian pasangan akan mempelawa untuk keluar bersama menikmati makanan. Kemudiannya, aktiviti berpasangan tersebut akan berkembang dan lama kelamaan pasangan akan bersama-sama menaiki kenderaan secara bersama (Utusan Malaysia, 2008). Proses janji temu bukan hanya sekadar makan tetapi berpegangan tangan dan seterusnya berlaku situasi tidak berakhlak tanpa mengenal batas tatasusila, pasangan akan mula tidur atas bahu kekasih dan kadang-kadang sampai melakukan penzinaan (Farid Ravi, 2008). Inilah asbab hujah Islam yang sama sekali menegah pergaulan bebas antara lelaki dan perempuan yang bukan mahram. Malah, Allah SWT berfirman dalam surah Al-Isra' ayat 32, yang membawa maksud;

\section{Dan janganlah kamu menghampiri zina, Sesungguhnya zina itu adalah satu perbuatan yang keji dan satu jalan yang jahat (yang membawa kerosakan).}

Justeru itu, peringatan dari firman Allah ini adalah jelas bahawa ianya adalah satu tegahan keras dari Allah SWT supaya jangan sekali-kali cuba menghampiri zina. Menurut Kaedah fekah juga telah termaktub bahawa 'setiap sesuatu yang membawa kepada perlakuan yang haram, maka hukum melakukan perkara tersebut adalah haram', serta tindakan untuk melakukan pencegahan adalah lebih baik dari mengubat. Walaupun terdapat larangan yang jelas berhubung pergaulan di antara bukan mahram, namun, janji temu diharuskan bagi mereka yang sudah bertunang. Ia hendaklah dengan izin wali perempuan dan bersama mahram ahli keluarga perempuan (Farid, 2008). Hal ini kerana, bertunang adalah lesen awal untuk seseorang itu mengenali tunangnya yang bakal menjadi pasangan hidupnya dengan lebih dekat lagi. Menurut Siti Hajar (1996), adab melihat pasangan dalam Islam adalah seperti berikut:

i. Tidak harus melihat kecuali muka, kedua belah tapak tangan (sesudah ia benar-benar ingin menikahinya).

ii. Harus; melihat berulang kali, kiranya perlu supaya gambaran orang yang akan dipinangnya itu melekat dalam pemikirannya.

iii. Harus; berbicara kepadanya (perempuan \& lelaki) di dalam majlis peminangan.

iv. Tidak harus bertemu (lelaki \& perempuan) melainkan wujud salah seorang mahram wanita yang dipinangnya. 
v. Islam melarang keras duduk bersendirian dengan wanita asing.

Namun di dalam Islam, proses janji temu walaupun sudah bertunang mestilah tetap dengan adab memelihara hak Allah. Hal ini kerana, Sabda Rasulullah SAW;

"Awaslah jangan ada seorang lelaki besendirian dengan seorang wanita keluar bermusafir dan jangan sampai seorang wanita kecuali bersamanya seorang mahramnya".

Ketika bertunang Islam menggalak untuk pasangan bertaaruf dengan berlandaskan batasan pergaulan yang ditetapkan. Bertunang hanyalah merupakan ikrar janji setia yang tidak akan mampu menghalalkan yang haram dan tidak mengharamkan yang halal. Ulama mengharuskan pertemuan lelaki dan perempuan selepas pertunangan semata-mata untuk melihat sifat zahirnya, seperti melihat kepada rupanya untuk mengenal pasti kesempurnaan fizikalnya (Dhani 2019). Selain itu, dalam tempoh bertunang tidak bermaksud pasangan bebas untuk keluar berdua sebaliknya pasangan digalakkan untuk mengeratkan hubungan bersama keluarga pasangan. Ini kerana dapat menyumbang kepada pembentukan keluarga bahagia. Para ulama mengharuskan pertemuan lelaki dan perempuan selepas pertunangan semata-mata untuk melihat sifat zahirnya, seperti melihat kepada rupanya untuk mengenal pasti kesempurnaan fizikalnya (Dhani, 2019). Bahkan, tidak ada pengenalan yang sempurna bagi seorang lelaki terhadap pasangan kekasihnya melainkan selepas perkahwinan.

\section{Cinta dalam PerspektifIslam}

Dalam agama Islam, cinta tidak dilihat dari sudut hubungan manusia sesama manusia sahaja, namun pengertian cinta lebih luas meliputi hubungan dengan Allah dan seluruh kehidupan manusia. Terdapat pelbagai pendapat tokoh-tokoh Islam berkenaan cinta seperti Imam Al-Ghazali yang melihat cinta sebagai unsur yang menyenangkan dan memberi tarikan dalam hati manusia. Imam Qayyim alJauziyah mengupas terperinci antara cinta manusia dan cinta ketuhanan yang saling berkait rapat antara satu sama lain.

Islam meletakkan cinta pada tempat yang tertinggi iaitu cinta suci kepada Yang Maha Pencinta dan menjadikannya agenda utama dalam kehidupan. Kemuliaan cinta terletak kepada individu yang terbabit dalam percintaan. Mahmud Asy-Syarif di dalam bukunya Al-Hubb fil Quran menyatakan;

\section{'Islam adalah agama cinta dan mukmin tidak merasakan manisnya iman sehingga ia merasakan hangatnya cinta'}

Menurut Ash-Sheikh Thaha Abdul Baqi Surur (2003), menyatakan bahawa apabila kerajaan cinta (kepada Allah) kian teguh bersemayam dalam kalbu, sudah pasti ketaatan akan kian terpaku. Adapun kemaksiatan itu terjadi kerana malapnya api cinta dan lemahnya pertahanan yang ada, memetik firman Allah dalam surah Al-Baqarah ayat 165 yang bermaksud;

\section{'Adapun orang-orang yang beriman, sangat cinta kepada Allah'}

Terdapat pelbagai pengertian cinta di dalam Al-Quran, salah satunya cinta diertikan sebagai kemahuan untuk berpasangan dalam menikmati keindahan dan kelazatan hidup. Cinta antara lelaki dan perempuan, ibu bapa dan anak, guru dan murid, nabi dan umat dan lain-lain. Namun, semua takrifan hubungan cinta menjurus kepada satu matlamat utama iaitu untuk menjadikan manusia mengingati dan berfikir akan kebesaran Allah sebagaimana yang dinyatakan dalam Quran surah az-Zariayat ayat 49 maksudnya iaitu;

'dan segala sesuatu kami ciptakan berpasang-pasangan supaya kamu mengingati kebesaran Allah'

Manusia yang hidup di dunia ini tidak lekang dengan ujian yang sering kali menewaskan batasan keimanan melalui cinta yang terbit dengan hawa nafsu semata. Walau bagaimanapun, Allah telah 
mengingatkan bahawa apa yang ada di sisi-Nya adalah lebih baik daripada cinta keduniaan ini. Allah berfirman dalam surah Ali-Imran, ayat 14, iaitu;

'Dijadikan indah pada (pandangan) manusia kepada kecintaan apa-apa yang diingini, iaitu wanita-wanita, anak-anak, harta yang banyak dari jenis emas, perak, kuda pilihan, binatang-binatang ternak dan sawah ladang. Itulah kesenangan hidup di dunia dan di sisi Allah tempat kembali yang baik (syurga)'

Selain itu, Islam menekankan kepada percintaan selepas ikatan pernikahan sebagai satu langkah terbaik dalam mencapai kebahagiaan dalam kehidupan. Cinta seharusnya berputik dan mekar selepas pasangan mendapat mandat dan pengesahan melalui pernikahan. Seterusnya, bagi menyuburkan cinta pasangan suami dan isteri hendaklah menghormati hak dan tanggungjawab kepada yang dicintai dengan penuh kecintaan serta kasih sayang.

Hakikatnya, takrifan cinta bergantung kepada penghayatan individu. Cinta merupakan anugerah tuhan yang agung dan paling murni sekiranya manusia dapat menilai kesuciannya. Cinta melahirkan sejenis rasa kebahagiaan bersama yang bukannya tuntutan tetapi kerelaan bersama dan bukan meminta tetapi memberi keikhlasan. Apabila membicarakan tentang soal cinta, golongan remaja cukup sinonim dengan perkara tersebut. Hal ini kerana, zaman remaja merupakan zaman permulaan cinta mekar dalam jiwa mereka terhadap pasangan. Remaja wanita dan lelaki selalunya akan terlibat dengan percintaan dan kebanyakannya akan menghadapi masalah atau terjerumus ke dalam hubungan yang boleh merosakkan diri mereka (Noraini Ahmad, 2001; Zulaiha et al., 2016).

\section{Solusi Terhadap Isu Seks Sebelum Nikah}

Perasaan cinta terhadap jantina yang berbeza adalah perasaan semula jadi dan anugerah yang unik daripada Allah SWT. Walau bagaimanapun, usaha menjadikan Allah SWT sebagai cinta utama adalah dituntut bagi setiap individu tidak kira peringkat usia dalam menjamin kebahagiaan di dunia dan akhirat. Apabila membincangkan berkaitan janji temu dan cinta, golongan yang sentiasa dikaitkan adalah golongan remaja. Ini kerana golongan ini sering kali terjerumus disebabkan oleh cinta. Menurut kajian Nasrudin et al., (2012) mendapati kebanyakan golongan remaja cenderung mendefinisikan hubungan seksual sebagai cara untuk menyatakan perasaan cinta dan kasih kepada pasangan. Walau bagaimanapun, Islam tidak sama sekali menafikan perasaan cinta yang turut didorong oleh keinginan seksual. Namun, Islam juga telah menetapkan garis panduan yang indah dengan meraikan perasan cinta yang hadir dan menyalurkan keinginan seksual terhadap pasangan melalui hubungan pernikahan. Pasangan berkahwin yang disuburkan lagi dengan perasaan cinta lebih bermotivasi untuk saling melengkapi serta memahami di antara satu sama lain. Banyak kajian mendedahkan, antara salah satu punca penceraian dalam pasangan suami isteri di Malaysia adalah tidak ada persefahaman antara pasangan (Mariam \& Mohammad Syafirul, 2017). Ini menjelaskan, perasaan cinta adalah penting dan perlu dipupuk dan disemai antara pasangan.

Menginjak usia remaja adalah normal untuk remaja mula tertarik dan meminati kepada individu berlainan jantina dan perasaan ini juga menunjukkan proses tarikan nafsu terhadap pasangan sesama jenis berlaku. Oleh itu, pada fasa ini adalah penting untuk remaja mengurus dan menyalurkan perasaan mereka pada tempat yang betul seiring dengan syariat Islam. Bahkan, di dalam Islam telah menggariskan beberapa adab mengenai pergaulan di antara lelaki sesama lelaki, dan juga wanita sesama wanita serta lelaki dan wanita. Ini dilakukan bagi memastikan ketenteraman masyarakat agar aspek seksualiti dan dorongannya mampu dibatasi sebelum ia menular ke kancah yang negatif. Menurut Siti Hajar (1996), terdapat beberapa adab seperti adab memandang yang biasa diajarkan kepada kanak-kanak, adab memandang mahram wanita, adab memandang wanita yang dilamar, adab seorang suami memandang isterinya, adab lelaki memandang wanita lain. Bahkan di dalam Islam juga terdapat adab lelaki memandang lelaki, adab wanita memandang wanita dan juga adab wanita memandang wanita lain. Ini membuktikan bahawa Islam itu cara hidup yang sempurna hinggakan ke segenap aspek seksualiti semasa turut sama telah diperbincangkan dan diperhalusi sebagai pencegahan awal ke arah kejadian-kejadian seksualiti negatif dan songsang. 
Di samping itu, bagi membantu remaja yang tercebur dalam kancah maksiat seks luar nikah, penglibatan ibu bapa adalah kunci utama. Sebagaimana perbincangan berkaitan dengan pembentukan keluarga bahagia, ibu bapa perlu memainkan peranan mendidik anak sejak kecil. Ibu bapa berterusan menyematkan dalam diri anak-anak bahawa cinta Allah adalah cinta teragung dan perlu mencintai Allah terlebih dahulu sebelum mencintai sesama makhluk serta menjauhi perkara mungkar yang dimurkai Allah SWT. Selain itu, kefungsian di dalam sesebuah keluarga juga dapat membantu remaja untuk menguruskan perubahan emosi, psikologi serta dorongan nafsu syahwat. Keluarga yang sering kali menunjukkan serta menyerlahkan kasih sayang di antara satu sama lain melahirkan remaja yang mementingkan, mengutamakan serta menghormati keluarga berbanding orang luar, termasuklah pasangan yang dicintai (Ezarina \& Norulhuda, 2019) serta elak mencemarkan nama baik keluarga. Ini menjelaskan faktor keluarga yang harmoni dan bahagia membantu remaja untuk tidak terjebak dengan isu-isu moral seperti seks luar nikah disebabkan oleh janji temu dan cinta yang tidak berlandaskan syariat Islam.

Begitu juga bagi keluarga yang mempunyai pemimpin atau ibu bapa yang menjalankan tanggungjawab dengan mendidik serta menerapkan nilai-nilai yang tinggi dalam diri anak-anak dapat menghindarkan anak-anak daripada terjerumus dengan janji temu atau cinta yang tidak sepatutnya (Rezki et al., 2019). Disulami pula dengan pendekatan keibubapaan yang selari dengan ajaran Islam dapat memperkukuhkan lagi perhubungan dalam keluarga. Di samping itu, ibu bapa yang meraikan perasaan cinta yang hadir dalam kalangan anak remaja mereka membuka ruang untuk anak-anak bebas berkongsi perasaan, pemikiran, dan pandangan dengan ibu bapa seterusnya meningkatkan lagi kebahagiaan dalam keluarga. Ibu bapa yang cenderung mendekati anak, mengenali pasangan cinta anak-anak serta menghampiri kenalan anak-anak dapat menyemarakkan lagi kebahagiaan dalam keluarga. Khadijah et al. (2012) turut menyokong keperluan ibu bapa untuk mengambil berat berkaitan dengan kenalan anak-anak. Dalam pada itu, ibu bapa juga mengambil peluang untuk memberi pandangan serta menyelitkan kata-kata nasihat untuk kebaikan anak-anak (Zulaiha et al., 2016). Begitu juga, dalam aspek janji temu dan cinta yang dialami oleh anak-anak, ibu bapa juga perlu mendidik anak-anak dengan menekankan batasan-batasan pergaulan antara jantina serta menanam sikap malu yang tinggi dalam diri anak-anak (Rezki et al., 2019).

\section{Kesimpulan}

Secara kebiasaannya, para remaja menginginkan kebebasan dari ikatan dan kongkongan ibu bapanya, tetapi pada masa yang sama, para remaja ini juga memerlukan bimbingan disebabkan oleh kurang pengalaman yang dilalui dalam kehidupan mereka. Remaja belum mempunyai kepercayaan pada diri sendiri dalam membuat keputusan. Oleh yang demikian, remaja sentiasa terumbang-ambing dengan perasaan yang tidak menentu antara kebebasan dan memerlukan perlindungan serta bimbingan daripada orang dewasa. Justeru, apabila ibu bapa, guru dan masyarakat tidak memainkan peranan masing-masing sebagai pembimbing, maka para remaja akan bergantung semata-mata pada rakan sebaya. Remaja bernasib baik apabila rakan mereka terdiri daripada individu yang berakhlak dan bertatasusila tinggi. Sebaliknya, apabila terlibat dalam pergaulan yang tidak dikehendaki, maka mereka terpaksa menurut tingkah laku rakan-rakan supaya diterima oleh kumpulan tersebut. Justeru, ibu bapa dan guru perlu mengekalkan perdampingan mereka dengan remaja dan mengambil berat kehidupan dan pergaulannya. Ibu bapa dan guru perlu memainkan peranan yang lebih bagi memastikan remaja berupaya mentafsir peranannya dalam masyarakat masa kini dan mendatang.

Dalam konteks ini, remaja tidak boleh lari daripada hidup bersosial seperti keluarga, rakan sebaya, sekolah dan masyarakat yang berkait rapat dengan perkembangan dirinya. Hasil interaksi yang saling mempengaruhi inilah yang membentuk cara pemikiran, emosi dan tindakan yang dilakukannya. Jawapan ke arah ini tidak lain tidak bukan ia terpulang kepada kita iaitu orang dewasa, sama ada para ibu bapa, guru, ilmuwan mahupun masyarakat umum. Sudah tiba masanya ibu bapa perlu berani dan tahu bagaimana untuk berkomunikasi dengan anak-anak tentang seksualiti ini. Komunikasi yang dimaksudkan termasuklah sama ada berbentuk akademik mahupun secara umum yang boleh disalurkan melalui pelbagai cara agar pendidikan berhubung seks sebelum berkahwin dapat difahami remaja serta mencegahnya dari berlaku. 


\section{Rujukan}

Abdul Munir. (2016). Pengaruh Media Massa Terhadap Akhlak Pelajar. International Conference on Education, Islamic Studies and Social Sciences Research.

Abdullah Nasih Ulwan. (2012). Pendidikan Anak-anak dalam Islam (Terj. Syed Ahmad Semait). Singapura: Pustaka Nasional Pte. Ltd

Abdullah Nasih Ulwan. (2007). Cinta dalam pandangan Islam. Terj. Bandung: Irsyad Baitus Salam.

Aida Adreena Shamsuddin. (2005). Hubungan Cinta Dalam Kalangan Remaja: Satu Tinjauan Kes

Sekolah Menengah Kebangsaan Sultan Abd Aziz Shah Kajang. Latihan Ilmiah. Universiti Malaya.

Ajmain@Jimaain Safar, Ab. Halim Tamuri \& Mohd Aderi Che Noh. (2012). Penghayatan Adab dan Akhlak Terhadap Alam Sekitar dalam Kalangan Pelajar Sekolah. Jurnal Teknologi (Social Sciences), 58, 1-11.

Arnett, J. J. (2001), Adolescence and emerging Adulthood. USA, Prentice-Hall, Inc.

Azizi Yahaya dan Asiah Suari. (2006). Fenomena Janjitemu, Cinta, Perlakuan Seks dan Hubungannya dengan Masalah Kebimbangan Sosial. Masters thesis, Universiti Teknologi Malaysia.

Azizi Yahaya, Cathy Suhaila Abdullah, Roslee Ahmad \& Sharifuddin Ismail. (2006). Punca dan Rawatan Kecelaruan Tingkah Laku. Kuala Lumpur, PTS Profesional Publishing Sendirian Berhad.

Convention on the Rights of the Child. (2008). Capaian pada 10 April 2020 dari http://cyberschoolbus.un.org/treaties/child.asp.

Dhani Ramdhani. (2019). Pergaulan Laki-Laki dan Perempuan Semasa Pertunangan Pada Keluarga Elit Agama dan Masyarakat Blater di Desa Kapedi. Al-Manhaj, 1(1), 31-42.

Ezarina Zakaria \& Norulhuda Sarnon. (2019). Ketidakfungsian Keluarga Remaja Perempuan Tidak Terkawal: Suatu Kajian Awal. GJAT, 9(3), 79.

Fadillah Ismail. (2016). Faktor Keharmonian dan Keruntuhan Rumah Tangga. PROSIDING PERKEM. 11: $394-399$.

Fauziah Ibrahim, Norulhuda Sarnon, Khadijah Alavi, Mohd Suhaimi Mohamad, Noremy Md Akhir \& Salina Nen. (2012). Memperkasakan pengetahuan agama dalam kalangan remaja bermasalah tingkah laku: ke arah pembentukan akhlak remaja sejahtera. e-BANGI: Jurnal Sains Sosial dan Kemanusiaan, 7(1), 84-93.

Glasser, W. (1999). Choice Theory: A New Psychology of Personal Freedom. Amerika: Harper Perennial

Gullotta, T.P., Adams G.R., Markstrom, C.A. (2000). The Adolescent Experience, fourth edition, U.S.A., Academic Press.

Hadis (Bukhari, No. 5090 dan Muslim, No.1466). Kementerian Kesihatan Malaysia. (2018). Statistik Remaja Hamil 2014-2018. Capaian pada 16 Oktober 2020 dari https://www.moh.gov.my/

Khadijah Alavi, Salina Nen, Fauziah Ibrahim, Noremy Md. Akhir, Mohd Suhaimi Mohamad,Noorhasliza Mohd Nordin. (2012). Hamil Luar Nikah Dalam Kalangan Remaja. Jurnal of Social Sciences and Humanity, 7(1), 131-140.

Mariam binti Abd Majid \& Mohammad Syafirul Zarif bin Saleh Hudin. (2017). Trend dan Faktor Perceraian Rumah Tangga di Negeri Selangor dari Tahun 2011 Hingga 2015. Al-Irsyad: Journal of Islamic and Contemporary Issues, 2(2), 40-53.

Mínguez, A.M. (2020). Children's Relationships and Happiness: The Role of Family, Friends and the School in Four European Countries. Journal Happiness Stud, 21, 1859-1878.

Mohamed Hatta. (1994). Psikologi \& Kaunseling Remaja. Kuala Lumpur: Vinlin Press Sdn Bhd.

Mohd. Fauzi, H., \& Mohd. Khairul Naim, C. N. (2012). Tinjauan Kepentingan Pembangunan

Modal Insan di Malaysia. Jurnal Al-Tamaddun, 7(1), 75-89.

Mohd Makzan Musa. (2001). Psikologi Sosial. Selangor: Percetakan Semarak Sdn. Bhd.

Mohd Noor, A. F., Jasmi, K. A. \& A Shukor, K. (2013). Masalah Sosial dalam Kalangan Pelajar dan Peranan Pensyarah Pendidikan Islam dalam Pengajaran dan Pembelajaran. Proceedings of the First Seminar on Islamic Education and Research at The Main Hall, Faculty of Islamic Cilization, Universiti Teknologi Malaysia on 17-18 September 2013.

Mohd Razimi Husin, Nur Syahira Sofia Mohd Suhairi, Wan Noraqilah Wan Aziz, Wan Muhammad Aiman Zukifli, Norul Alia Ismail, Ernadia Hazlin Mohd Hata, Sharifah Rashidah Syed Mohmad 
Rashid, Venusha Segar \& Faradyna Shafeena Effendy. (2020). Masalah Berpasang-pasangan dalam Kalangan Pelajar Sekolah. Journal of Humanities and Social Sciences, 2(1), 1-12.

Nabilah Huda Zaim, Norsaleha Mohd Salleh. (2019). Kesejahteraan Keluarga di Malaysia: Suatu Sorotan Awal. Jurnal Sultan Alauddin Sulaiman Shah, 27-36.

Nasrudin Subhi, Radhiah Abu Bakar, Norazura Ahmad, Suzana Mohd Hoesni, Fauziah Ibrahim \& Mohd Suhaimi Mohamad. (2012). Hubungan Seksual Remaja: Antara Cinta Dan Nafsu (Sexual Relationship Among Adolescent: Between Love and Lust. Journal of Social Sciences and Humanities, 7(1), 15-25.

National Health \& Morbidity Survey. (2017). Sex and Teens: What is Going on in Malaysia. Capaian pada 1 Oktober 2020 dari http://www.iku.gov.my/nhms

Nik Norliati Fitri Md Nor \& Suriati Ghazali. (2016). Peranan Anak Lelaki sebagai Penjaga Utama Warga Tua Melayu di Luar Bandar: Kajian Kes di Daerah Jerantut, Pahang. Geografi, 4(1), 2534.

Nina Surtiretna. (1998). Bimbingan Seks Menurut Pandangan Islam dan Perubatan. Selangor: Thinker's Library Sdn. Bhd.

Nurul Wahidah Fauzi, Siti Nor Baya Yaacob, Syaimak Ismail \& Nasaruddin Yunus. (2015). Konsep dan Perspektif Cinta Hakiki: Empat Pendekatan Cinta Dalam Mursyid Al-Syabab oleh Bediuzzaman Said Nursi Dan Al-Ghazali di dalam Ihya Ulumuddin. Proceedings of ICIC2015 International Conference on Empowering Islamic Civilization in the 21st Century: 724-733.

Nur Zahidah Jaapar \& Raihanah Azahari. (2011). Model Keluarga Bahagia Menurut Islam. Jurnal Fiqh, 8, 25-44.

Rezki Perdani Sawai, Syaidatun Nazirah Abu Zahrin, Sidek Mohd Noah, Rumaya Juharid \& Steven Eric Krauss. (2019). Akhlak Percintaan dan Rasa Malu. Al-'Abqari Journal of Islamic Social Sciences and Humanities, 18.

Safeek Affendy Razali. (2019). Dua Kementerian Bincang Mengenai Pendidikan Seks. Capaian pada 4 Oktober 2020 dari https://www.bharian.com.my/berita/pendidikan/2019/01/518350/2kementerian-bincang-mengenai-pendidikan-seks

Shuhairimi \& Huzaili. (2012). Eksprektasi Antara Hasrat dan Realiti Wanita Bekerjaya Terhadap Pengurusan Kekeluargaan. Journal of Human Development and Communication, 1, 107-127.

Siti Zuriyani Tumain. (2006). Hanya lelaki; meneroka 1001 rahsia diri. Selangor: Dasar Cetak (M) Sendirian Berhad.

Syah Rizal, Hamdi Ishak \& Najah Nadiah Amran. (2017). Hubungan Antara Amalan Ibu Bapa Dengan Tingkah Laku Remaja. Proceedings of the International Conference on Islam, Development and Social Harmony in Southeast Asia, 261-267.

Syaidatun Nazirah Abu Zahrin, Fazilah Idris, Fariza Md Sham, Rezki Perdani Sawai \& Joki Perdani Sawai. (2014). Psikologi Agama dalam Menangani Gejala Sosial Remaja. Malaysian Journal of Youth Studies, 187-203.

Syeikh Ghazali Abd. Rahman. (2000). Memasuki Gerbang Perkahwinan. Malaysia. Jabatan Kemajuan Islam Malaysia.

Thalhah Ajmain \& Ahmad Ezzuddin. (2019). Kaedah dan Ciri Pendidikan dalam Melahirkan Sebuah Keluarga yang Sejahtera. Seminar Kebangsaan Keluarga Sejahtera Negeri Johor.

Thomas Jay Oord. (2010). Defining Love: A Philosophical, Scientific, and Theological Engagement. Amerika: Brazos Press.

Valeria.V., Giuseppe R., Valeria. S., Jessica P., Roberto B. \& Lilybeth. F. (2020). Personal and Family Correlates to Happiness amongst Italian Children and Pre-adolescents. International Journal of Emotional Education, 12 (1), 48 - 64.

Zainal Madon \& Mohd. Sharani Ahmad. (2006). Panduan Mengurus Remaja Moden. Pahang: PTS Publication

Zaiton Mu'tadin. (2002). Pendidikan seksual pada remaja. Capaian pada 13 Ogos 2020 dari http://www.wattpad.com/77072-pendidikan-seksual-pada-remaja

Zulaiha, Ali Othman, Roslan Ahmad, Umi Nadzrah \& Zurina Muda. (2016). Remaja Bercinta: Kajian Terhadap Tiga Jenis Sekolah Menengah Kebangsaan, Agama dan Agama Swasta. Jurnal Hadhari, 8(1), 187-210. 